\title{
ENTREPRENEURIAL COMPETENCES IN CONTEMPORARY MANAGEMENT
}

\author{
Marijan Cingula* \\ Faculty of Economics, University of Zagreb, Zagreb, Croatia
}

\begin{abstract}
Managerial as well as entrepreneurial skills are necessary for leaders in turbulent global environment. The research goal of this paper is to show how generally accepted entrepreneurial competences fit into modern management activities. Author is seting hipothesis that fundamentals of managerial competences can be recognized in entrepreneurial behavior, so fostering entrepreneurship can improve the management process. The main research question is whether one can talk about entrepreneurship in large and medium-sized businesses, in other words, can one identify the entrepreneurial approach in contemporary management, and can it be expected that today's managers possess entrepreneurial skills? It is important to recognize that fostering entrepreneurship can improve the process of management and enable leaders to encourage employees to behave in more creative and innovative manner, in order to achieve and sustain competitive position on the market place in a long run.
\end{abstract}

Keywords: management, entrepreneurship, competences, skills

\section{JEL Classification: M10}

\section{INTRODUCTION}

Entrepreneurship is the process by which individuals pursue opportunities without regard to resources they currently control. Entrepreneurial firms are proactive, innovative and risk taking. They bring new products and services to market by creating and seizing opportunities regardless of the resources they currently control. There is strong evidence that entrepreneurial behavior has strong impact on economic stability and strength. The areas in which entrepreneurial firms

\footnotetext{
* Correspondence to: M. Cingula, Faculty of Economics, University of Zagreb, J. F. Kennedy 6, 10000 Zagreb, Croatia; e-mail: mcingula@efzg.hr
}

contribute the most are innovation, job creation and globalization (Barringer \& Ireland, 2006, 4-16).

There are many modern managerial theories, but not one like entrepreneurial, though in many such theories one can find some ideas very close to creativity and innovativeness, which are already recognized as major entrepreneurial competences (Drucker, 1985). It is very easy to identify different entrepreneurial aspects in managerial theories, though there are no field researches to support any statistical correlation between entrepreneurial behavior and managerial efficiency. If the knowledge of the organization, including the resources management, as well as leading and managing the people, together with 
effective communication, builds the fundamentals of managerial competences, then many modern approaches to the managerial process can be directly connected to the entrepreneurship.

The hypothesis 1 (H1): Fundamentals of managerial competences can be recognized in entrepreneurial behavior, so fostering entrepreneurship can improve the management process

There are several ways of interpreting the importance of entrepreneurship for the entire national economy. The most common way is through statistic indicators that describe the significant share of employment in small and medium-sized enterprises. In addition, contribution of small and medium-sized enterprises to total national income is also measured. Add to this the data for the sole proprietors, craft cooperatives and traders, in some countries both indicators rise above $50 \%$, which certainly confirms that entrepreneurship is a vital part of the economic life of any country (Dalberg Report, 2011). There are, however, different views according to which the importance of entrepreneurship outperforms only one segment of the national economy, regardless the share of its overall activities and results. Small and mediumsized enterprises, cooperatives and crafts undoubtedly determine the economic development and contribute to the general welfare, but the competitive advantage of a country is primarily defined by the international trade success of large and medium-sized enterprises. The question arises, whether one can talk about entrepreneurship in large and medium-sized businesses, and can one talk about the contribution of entrepreneurship to economic development by looking at the largest economic entities in different countries? This question does not apply to the existence of entrepreneurial projects that are conducted through collaboration with large corporations, but rather wants to emphasize the importance of entrepreneurial behavior within the ordinary course of business and management of large enterprises. In other words, can one identify the entrepreneurial approach in contemporary management, and can it be expected that today's managers possess entrepreneurial skills? The answers to these questions can be found in works of authors who have written about management and entrepreneurship.

\section{CONTEMPORARY MANAGEMENT AND ENTREPRENEURHIP}

Today's modern world is dominated by political and financial oligarchies that, at the level of national states, direct taxpayer's money into the battered private sector, in order to revive the economic activity and overcome the national economic crisis. It is not difficult to see how such actions are implemented to save big bankers and capitalists, who have not renounced the extra profit, despite poorly managing their corporations and actually causing the aforementioned crisis (Elliott, 2011). The initial function of the national economy: to create enough goods and services to satisfy the needs of the population, and allow the free market exchange, apparently gave way to streamlining state interventionism towards the interests of a privileged elite. Therefore it is necessary to include factors of social responsibility and common welfare into the discussion on the effects of the national economy, both on the national and the global level. In other words, social responsibility and the common welfare should be the fundamental criterion for economic activities, rather than predatory profit maximization. Individual welfare depends, without a doubt, on a number of factors that can be classified as individual (subjective), and those external, which depend on the creation of national wealth, i.e. the dynamics of the national economy. External factors are being derived from the competitive capacity of enterprises, that is, the joint abilities of entrepreneurs and managers. That is why it is interesting to see whether the entrepreneurial behavior of managers can be considered in the context of modern management theory. Behavioral differences between entrepreneurs and managers exist because the entrepreneur is primarily oriented to the acceptance of risk, profit making and intuitive decision making, whereas the manager is focused on increasing the capital value for investors, while trying to minimize the risk by using sophisticated analytical procedures and rational decision making. In relation to his associates, the manager is a leader, as well as a motivator, whereas the entrepreneur is often just a "commander". Proactivity is their common characteristic, and creativity is also desirable feature for the both of them. In his analysis of management roles, H. Mintzberg (1973) emphasized the importance of the 
entrepreneurial role stating that the contemporary manager has to base his success on characteristics typical for an entrepreneur.

Many contemporary management theories contain parts that show the importance of behavior for the managers' success, even if the expected entrepreneurial characteristics are not explicitly marked. For example, self-dettermination theory developed in the works of Deci and Ryan (2000) states that an individual cannot work under the influence of two types of motivation. Controlled motivation creates a sense of obligation and compulsion for the individual, and is thus similar to the typical managerial behavior. Autonomous motivation is a sense of independence for the individual and leads to the formation of the so-called "ownership" effect which brings the concept close to the entrepreneurial behavior. The learning organization, according to Argyris (1993) and Senge (1994), implies two types of learning: adaptive and generic learning. Adaptive learning, typical for managers, is related to past experiences and it is based on applying a series of small changes that will gradually lead to behavioral improvements. Generic learning, on the other hand, emphasizes continuous experimentation and seeking solutions in a given moment, which is a characteristic of entrepreneurial behavior. Coaching has long been present in the concept of management, and the method has been evaluated as a very effective in organizing and motivating associates to achieve higher levels of personal effectiveness through improving leadership skills, establishing individual responsibility, encouraging teamwork, supporting sales, fostering communication, setting objectives and implementing the business strategy. Unlike mentoring, the coach does not necessarily have to be an expert in the area he teaches, thus the behavior of managers in the coaching process is somewhat similar to the behavior of entrepreneurs. The dynamic-capabilities theory (Teec et al, 1997), especially in its extension to the resource-based theory, stresses the importance of adapting the organizational resources (valuable, rare and irreplaceable) to changes in technology, which completely coincides with entrepreneurial behavior. An also interesting theory is the stupidity-based theory (Alvesson \& Spicer, 2012), which assumes that contemporary organizations builds success on the mobilization of cognitive abilities, but there are some restrictions that lead to the emergence of functional stupidity. These restrictions relate primarily to the absence of reflexivity, poor use of intellectual abilities and avoiding inspection and reasoning. Limitations of cognitive abilities were observed in earlier theories, such as: bounded rationality (Simon, 1972) which is based on the lack of time, information and processing capabilities. Concept of skilled incompetence (Argyris, 1986) recognizes that continuous use of skills leads to routine so managers over time begin to play it safe in order to avoid any surprises, embarrassment and threats. Organizational irrationality has been recognized by numerous authors, such as Brunsson (1985), March and Simon (1958), Wagner (2002), who all noted that cognitive limitations lead to partly rational decisions.

Other contemporary theories dealing with the analysis of behavior and motivation can be observed in the same way: similar factors motivate both entrepreneurs and managers, and it can be concluded that modern managers must incorporate an entrepreneurial "code", mostly as a creative way to solve problems and the ability to take risk in a turbulent environment. This is important in emphasizing the importance of entrepreneurship in modern economic development. Since the economies of most countries are burdened with the economic crisis, which is even more expressed in the transition countries of Central and Eastern Europe, it is quite reasonable to expect that only entrepreneurship and entrepreneurial behavior can help overcome economic downturns and create the conditions for a new momentum towards the prosperity of individuals and national economies.

\section{CONTEMPORARY MANAGERIAL SKILLS AND COMPETENCES}

Managerial skills are generally, well developed in literature, and there are many authorities specifying what is the most important for successful management. Different approaches are selected in Table 1, just to show typical skills, recognized through relevant researches by both business professionals and academic institutions. 
Table 1 Different approaches to the managerial skills

\begin{tabular}{|c|c|c|}
\hline Source & & ills \\
\hline Typical and generally accepted & $\begin{array}{l}\text { Verbal communication (including listening) } \\
\text { Managing time and stress } \\
\text { Managing individual decisions } \\
\text { Recognizing, defining, and solving problems }\end{array}$ & $\begin{array}{l}\text { Setting goals and articulating a vision } \\
\text { Self-awareness } \\
\text { Team building } \\
\text { Managing conflict } \\
\text { Delegating } \\
\text { Motivating and influencing others }\end{array}$ \\
\hline $\begin{array}{l}\text { Carnegie Mellon University } \\
\text { (CMU) }\end{array}$ & $\begin{array}{l}\text { Analysis } \\
\text { Individual Leadership (Influence) } \\
\text { Oral Communication } \\
\text { Customer Service Orientation } \\
\text { Initiative } \\
\text { Organizational Awareness } \\
\text { Delegation } \\
\text { Judgment } \\
\text { Quality Management }\end{array}$ & $\begin{array}{l}\text { Talent Managing } \\
\text { Teamwork Management } \\
\text { Empowerment } \\
\text { Maximizing Performance } \\
\text { Written Communication } \\
\text { Follow-up } \\
\text { Negotiation } \\
\text { Developing Organizational Effectiveness }\end{array}$ \\
\hline Harvard Business School & $\begin{array}{l}\text { Decision-Making } \\
\text { Negotiating \& Influencing } \\
\text { Delegating Effectively } \\
\text { Developing Leadership Skills } \\
\text { Fostering Leadership Talent }\end{array}$ & $\begin{array}{l}\text { Nurturing Emotional Intelligence \& Thought } \\
\text { Leadership } \\
\text { Resolving Workplace Conflict } \\
\text { Styles \& Qualities Of Leaders }\end{array}$ \\
\hline $\begin{array}{l}\text { Andersen Consulting (2000), } \\
\text { in: Introduction to developing } \\
\text { management skills }\end{array}$ & $\begin{array}{l}\text { Creativity } \\
\text { Less controlling } \\
\text { Team building } \\
\text { Shares authority } \\
\text { Resilience/flexibility } \\
\text { Culturally attuned } \\
\text { Technical competence } \\
\text { Encourages challenge } \\
\text { Deal with ambiguity }\end{array}$ & $\begin{array}{l}\text { Clear vision } \\
\text { Speed } \\
\text { Comfortable with risk } \\
\text { Emotional intelligence } \\
\text { Creates a motivated business } \\
\text { Communication skills } \\
\text { Manages intellectual diversity } \\
\text { Entrepreneurial }\end{array}$ \\
\hline $\begin{array}{l}\text { American Management Associa- } \\
\text { tion (2000), in: Introduction to } \\
\text { developing management skills }\end{array}$ & $\begin{array}{l}\text { Customer Focus } \\
\text { Ability to use information to solve problems } \\
\text { Recognizing problems and implementing } \\
\text { solutions } \\
\text { Credibility among peers, subordinates, col- } \\
\text { leagues } \\
\text { Ability to transform words into actions } \\
\text { Contributing to firm mission/objectives }\end{array}$ & $\begin{array}{l}\text { Identifying opportunities for innovation } \\
\text { Setting standards for self and subordinates } \\
\text { Coaching and mentoring skills } \\
\text { Time management } \\
\text { Implementing improvements } \\
\text { Setting priorities } \\
\text { Working in teams (cooperation/commitment) } \\
\text { Listening and asking questions }\end{array}$ \\
\hline $\begin{array}{l}\text { George Mason University, Infor- } \\
\text { mation Technology Unit (ITU), } \\
\text { in: The 8th Voyager }\end{array}$ & $\begin{array}{l}\text { Knowing the Organization } \\
\text { Leading and Managing People } \\
\text { Managing Resources } \\
\text { Communicating Effectively }\end{array}$ & \\
\hline
\end{tabular}

These skills of modern managers are accepted both in theory and in practice, and they are seen as typical characteristics of successful leaders and business people. It is beyond doubt that the manager also performs a variety of tasks, including technical, financial and communication aspects, and thus it is necessary to possess different skills.

Technical aspects of managerial jobs are related to the "hard" components of an organization, such as 
technology, machinery, equipment, raw materials, in short all the physical and material resources that are involved in manufacturing and technical systems. Technical aspects are used in the process of planning, organizing and controlling, and at first glance they appear to be the dominant managerial jobs in business organizations. However, management of material resources is only one aspect of the manager's job, and the skills needed are shown in Table 2.

Table 2 Technical managerial skills

\begin{tabular}{lll}
\hline Technical & Analysis & Implementing im- \\
skills & Recognizing, definng, & provements \\
& and solving problems & Setting priorities \\
& Quality Management & Ability to use informa- \\
& Technical competence & tion to solve problems \\
Speed & Managing resources \\
Comfortable with risk & Knowing the organiza- \\
Recognizing problems & tion \\
and implementing & Creativity \\
solutions & Working in teams \\
Time management & (cooperation/commit- \\
& ment) \\
& Decision-Making \\
& Effectiveness \\
\hline
\end{tabular}

Source: Author

All these skills are listed in Table 1 under a variety of sources, and some are stated more than once. Their importance is primarily directed towards developing the ability to identify and eliminate technical stoppages, as well as towards the formation of an organization (its structure and processes) that will best support the implementation of business strategy. Since these skills are developed primarily on faculties of Natural Sciences and Technology, it is not unusual that many engineers and mathematicians, as well as technology experts are at the same time highly successful managers.

Financial aspects of the manager's job are related to managing of resources in order to achieve a positive result in the short term, and to increase owners' property in the long term. This aspect is present in all management processes, from planning, organizing to human resources management and control. Since this aspect is most exposed to the public eye, dominant in the annual financial reports, and synthetically expressed through a series of economic and financial indicators, it can be concluded that the skills needed to manage the aspect are also very important, and are summarized in Table 3.

Table 3 Financial managerial skills

\begin{tabular}{lll}
\hline $\begin{array}{l}\text { Financial } \\
\text { skills }\end{array}$ & $\begin{array}{l}\text { Setting goals and articu- } \\
\text { lating a vision }\end{array}$ & $\begin{array}{l}\text { Recognizing problems } \\
\text { and implementing solu- }\end{array}$ \\
& Managing time and & tions \\
stress & Working in teams (coop- \\
Managing resources & eration/commitment) \\
Contributing to firm mis- & Comfortable with risk \\
sion/objectives & Clear vision \\
Ability to transform & Creativity \\
words into actions & Decision-making \\
Setting priorities & Customer service orien- \\
Credibility among peers, & tation \\
subordinates, col- & Initiative \\
leagues & Maximizing perfor- \\
Time management & mance \\
Customer focus & Written communication \\
& Effectiveness \\
\hline
\end{tabular}

Source: Author

A cursory overview of the aforementioned skills shows that they are dominated by the economic and communication aspects, complemented by some technical aspects. It is normal to expect that skills necessary to manage the financial aspects of managerial work are gained mostly through education in economics. It is also obvious that the emphasis is not only on the financial and quantitative analysis, but rather on market orientation and customer relationship management.

Communicative aspects of managerial jobs are primarily related to human resource management, especially to the process of leadership, staffing and motivating. Table 4 shows research results, i.e., it shows dominant skills related to the aspect.

Mastering the skills presented will certainly help in creating a better organizational climate, developing an adequate managerial style and establishing a corporate 
Table 4 Communication managerial skills

\begin{tabular}{lll}
\hline $\begin{array}{l}\text { Commu- } \\
\text { nication } \\
\text { skills }\end{array}$ & $\begin{array}{l}\text { Verbal communication } \\
\text { (including listening) }\end{array}$ & $\begin{array}{l}\text { Setting standards for } \\
\text { self and subordinates }\end{array}$ \\
& $\begin{array}{l}\text { Managing time and } \\
\text { stress }\end{array}$ & $\begin{array}{l}\text { Coaching and mentor- } \\
\text { ing skills }\end{array}$ \\
& Managing individual & Time management \\
decisions & Implementing improve- \\
Recognizing, defining, & ments \\
and solving problems & Setting priorities \\
Setting goals and & Working in teams \\
articulating a vision & (cooperation/commit- \\
Self-awareness & ment) \\
Team building & Listening and asking \\
Managing conflict & questions \\
Delegating & Less controlling \\
Motivating and influ- & Team building \\
encing others & Shares authority \\
Credibility among & Resilience/flexibility \\
peers, subordinates, & Culturally attuned \\
colleagues & Encourages challenge \\
Deal with ambiguity & \\
\hline
\end{tabular}

Source: Author

culture that will contribute most to the achievement of the business strategy.

If one does a comparison of the modern companies, it is evident that the companies must use the latest technology in order to succeed in the field. When the differences in technical systems are small, creating a competitive advantage depends on better organized and more motivated people. Therefore, managerial skills, focused on the development and implementation of individual creativity are very important for the overall business success.

Among the technical, financial and communication skills of modern managers, there are some skills that are considered universal because they are mentioned in the review of each of these groups. Their study could lead to a focus on the core of management, i.e. it would help identify the key competences of a manager in modern business organizations. These "universal" skills are shown in Table 5.

If these, basic managerial skills are observed in the context of entrepreneurial behavior, it is evident that there is a great similarity between managerial skills
Table 5 Core managerial skills

\begin{tabular}{lll}
\hline Core & Analysis & Resilience/flexibility \\
manage- & Recognizing, defining, & Encourages challenge \\
rial skills & and solving problems & Deal with ambiguity \\
& Speed & Recognizing, defining, \\
& Comfortable with risk & and solving problems \\
Implementing improve- & Setting goals and articu- \\
ments & lating a vision \\
Setting priorities & Self-awareness \\
Ability to use informa- & Customer focus \\
tion to solve problems & Creativity \\
& Managing resources & Decision-making \\
Knowing the organiza- & \\
tion & \\
\hline
\end{tabular}

Source: Author

and entrepreneurial behavior. This is exactly what wants to be emphasized in this analysis: managerial skills are largely based on entrepreneurial behavior, which means that the adoption of entrepreneurial behavior is necessary for the development of managerial skills.

\section{MANAGEMENT ENTREPRENEURIAL SKILLS IN CONTEMPORARY ENVIRONMENT}

The overview of managerial skills has proved that there are some universal or core values that can define managerial behavior, thus it is also possible to identify the key components of entrepreneurial behavior and business. Different authors define different characteristics of entrepreneurs, and the most common dispute is about the element that predominantly determines entrepreneurial behavior - is that risk-taking or is it creativity (Drucker, 1985). Many managerial competences are seen as tipically entrepreneurial, according to UK Center for Bioscience (2013):

- management skills - the ability to manage time and people (both oneself and others) successfully

- communication skills (e.g. the ability to sell ideas and persuade others) 
- the ability to work both as part of a team and independently

- ablilty to plan, coordinate and organise effectively

- financial literacy

- ablility to research effectively (e.g. available markets, suppliers, customers and the competition)

- self-motivated and disciplined

- adaptability

- an innovative and creative thinker

- the ability to multi-task

- able to take responsibility and make decisions

- the ability to work under pressure

- perseverance

- competitiveness

- willingness to take risks (or at least not risk averse)

- ability to network and make contacts.

Somewhat different skills, required for an entrepreneur to have, are, given in the description of the practical knowledge necessary for business success. StrategicBusinessTeam.com, an online blog for entrepreneurs who are just starting their ventures, suggests these necessary characteristics:

- personal skills

- communication skills

- negotiation skills

- leadership skills

- sales skills.

This list of skills points out a number of practical skills that a good businessman must have, and it is very similar to the description of a successful trader in the book that was written more than five hundred years (Kotruljević, 1985). Since entrepreneurs are expected to be familiar with the technology of his enterprise and that is usually dominant to his advantage. In addition to the technical aspects, it is necessary to know the economic-financial and legal aspects of business, and then come all the other communicational abilities that help in the development of interpersonal relationships within the company, and his associates, as well as outside the company, with customers. Behavioural charcteristics of entrepreneurs are especially stressed in literature (Timmons et al, 1977):

- drive and energy

- self-confidence

- high initiative and personal responsibility

- internal locus of control

- tolerance of ambiguity

- low fear of failure

- moderate risk taking

- long-term involvement

- money as a measure not merely an end

- use of feedback

- continuous pragmatic problem solving

- use of resources

- self-imposed standards

- clear goal setting.

Entrepreneurs are expected to be familiar with the technology of their enterprise and that is usually their dominant advantage. In addition to the technical aspects, it is necessary to know the economic, financial and legal aspects of business, as well as to have communication abilities that help to develop interpersonal relationships within the company, but also outside the company, where one has relationships with the consumer.

Previous surveys on skills that are needed for contemporary managers and entrepreneurs have shown some overlap, i.e. there are opinions according to which both need the same knowledge, skills and ways of behavior. Experts at Anderson Consulting explicitly state that a manager has to be entrepreneurial, while the UK Centre for Bioscience, stresses that managerial skills are vital for entrepreneurs. This is by no means accidental, since the actual daily activities of both managers and entrepreneurs coincide to a large extent. Both are exposed to a turbulent environment, and both need to be focused on the customer needs, so the operational position is almost identical for both. The difference in ownership is almost negligible, especially at a time when the need for socially responsible behavior and guarding the interests of all stakeholders is strongly emphasized. 


\section{CONCLUSION}

The early twenty-first century is a time when entrepreneurial actions are recognized widely as a path to competitive advantage and success in organizations of all types and sizes. Moreover, a lack of entrepreneurial actions in today's global economy is a recipe for failure (Morris et al, 2008, 419-421). The job of management effectively becomes one of continual experimentation with new methods, new products, new skills, new reward systems, and much more. The quest remains the same, to achieve sustainable competitive advantage. Achieving an entrepreneurial orientation is not something that management can simply decide to do. By their nature, organiyations impose constraints on entrepreneurial behavior. Flexibility, speed, innovation and entrepreneurial leadership are the cornerstones. The managerial mindset must become an oppotynity driven mindset, where actions are not constrained by resources currently controlled.

There are many separated surveys focused on finding out which managerial or entrepreneurial skills are important for individuals who are involved in running their own business or in taking care of a corporation. Some of the results show how both managerial and entrepreneurial skills are necessary for leaders in turbulent global environment. It is important to recognize that fostering entrepreneurship can improve the process of management because the fundamentals of managerial competences are recognized in entrepreneurial behavior. These fundamentals are useful for leaders in small and medium sized entreprises, as well as for leaders in corporations or even for political leaders too. Selfconfidence, motivation, discipline and a lot of energy at work, risk taking, strategic approach, as well as continuous pragmatic problem solving, are definitely very important skills in contemporary management of business and public organizations. Academics who recognize the importance of entreprenership for many other fields of work, suggest to raise the level of academic work in the field of entrepreneurship, in methodological rigor, conceptual depth, and managerial applicability. Therfore, initial hypothesis, claiming that fundamentals of managerial competences can be recognized in entrepreneurial behavior, so fostering entrepreneurship can improve the management process, is confirmed.

The entrepreneurial orientation for organizations in twenty-first century can be the new intersection of the creative power of entrepreneurs with the economic engines of organizations. In future, research efforts should be more focused on technolgy, experimental change and global competition. The new millennium is called an age of turbulence and paradox, but more suitable term would be the entrepreneurial age.

\section{REFERENCES}

Alvesson, M., \& Spicer, A. (2012). A stupidity-based theory of organization. Journal of Management Studies, 49(7), 1194-1220.

Argyris, C. (1986). Skilled incompetence. Harvard Busines Review, 74-79.

Argyris, C. (1993). Knowledge for action. A guide to overcoming barriers to organizational change. San Francisco: Jossey Bass.

Barringer, B. R., \& Ireland, R. D. (2006). Entrepreneurship: Successfully launching new ventures. New York, Pearson Education Inc., Upper Saddle River.

Brunsson, N. (1985). The irrational organization: Irrationality as a basis for organizational action and change. Hoboken: Wiley and Sons.

Deci, E. L., \& Ryan, R. M. (2000). The "what" and the "why" of goal pursuits: Human needs and the self-determination of behavior. Psychological Inquiry, 11, 227-268.

Drucker, P. F. (1985). Innovation and entrepreneurship: Practice and principles. New York: Harper \& Row.

Elliott, L. (2011). Global financial crisis: five key stages 20072011. The Guardian, August, 7th

Kotruljević, B. (1985). O trgovini i savršenom trgovcu. Zagreb: JAZU.

March, J. G., \& Simon, H. A. (1958). Organizations. New York: John Wiley.

Mintzberg, H. (1973). The nature of managerial work. New York: Harper \& Row.

Morris, M. H., Kuratko, D. F., \& Covin, J. G. (2008). Corporate entrepreneurship and innovation. 2nd ed., Mason, Thomson South-Western. 
Senge, P. et. al. (1994). The fifth discipline fieldbook: Strategies and tools for building a learning organization. Nicholas Brealey Publishing.

Simon, H. (1972). Theories of bounded rationality. In C. B. McGuire, \& R. Radner (Eds.), Decision and organization. Amsterdam: North-Holland Publishing Company.

Teec, D. P., Pisano, G., \& Shuen, A. (1997). Dynamic capabilities and strategic management. Strategic Management Journal, 18(7), 509-533.

Timmons, J. A., Smollen, L. E., \& Dingee, A. L. M. (1977). New venture creation: A Guide to entrepreneurship. Illinois: Richard D. Irwin, Inc. Homewood.

Wagner, D. G. (2000). On the irrationality of rejecting falsified theories. Sociological Focus, 32, 27-39.

Dalberg Report on Support to SMEs in Developing Countries Through Financial Intermediaries, Retrieved January 31st, 2013, from http://www.eib.org/attachments/dalberg_smebriefing-paper.pdf
Harvard Business School, Entrepreneurial Management, Retrieved November 23rd, 2012, from http://www.hbs.edu/ faculty/units/em/Pages/default.aspx

Introduction to developing management skills, University of Michigan The Ross School of Business, Retrieved January 7th, 2013, from http://webuser.bus.umich.edu/cameronk/PDFs/ Management\%20Skills/MANAGEMENT\%20SKILLS\%20 BOOK\%20(6TH\%20ED)\%20-\%20INTRODUCTION.pdf

The 8th Voyager, The 4 Pillars of Managerial Competencies, Retrieved January 7th, 2013, from http://voyager8.blogspot. com/2009/01/4-pillars-of-managerial-competencies.html

Typical Management Competencies Retrieved January 7th, from 2013, http://www.cmu.edu/hr/recruit_staff/forms/ CompetenciesManagers.pdf

UK Center for Bioscience, What are regarded as entrepreneurial skills? Retrieved February 2nd, 2013, from http://www. bioscience.heacademy.ac.uk/resources/entrepreneurship/ skills.aspx

Marijan Cingula is a professor of Strategic Management and Corporate Governance, and the Head of the MSc course in Business System Management at Faculty of Economics, University of Zagreb, Zagreb, Croatia. He gained his PhD Economics, at the same university. He is the elected president of the Croatian Association of Certified Board Members. 


\title{
PREDUZETNIČKE KOMPETENCIJE U SAVREMENOM UPRAVLJANJU
}

\author{
Marijan Cingula \\ Ekonomski Fakultet Unvierziteta u Zagrebu, Zagreb, Hrvatska
}

\begin{abstract}
Upravljačke, kao i preduzetničke veštine, neophodne su liderima u turbulentnom globalnom okruženju. Istraživački cilj ovog rada je da se prikaže način na koji se opšteprihvaćene preduzetničke kompetencije uklapaju u aktivnosti modernog upravljanja. Autor postavlja hipotezu da se temeljna načela upravljačkih kompetencija mogu prepoznati u preduzetničkom ponašanju, tako da se podsticanjem preduzetništva može unaprediti proces upravljanja. Glavno istraživačko pitanje je da li se može govoriti o preduzetništvu u velikim i srednjim preduzećima, ili, drugim rečima, da li se preduzetnički pristup može identifikovati u savremenom upravljanju, i da li se od današnjih menadžera može očekivati da poseduju preduzetničke veštine. Važno je prepoznati činjenicu da se podsticanjem preduzetništva može unaprediti proces upravljanja i omogućiti liderima da ohrabre zaposlene da budu kreativniji i inovativniji kako bi ostvarili i dugoročno održali svoj konkurentan položaj na tržištu.
\end{abstract}

Ključne reči: upravljanje, preduzetništvo, kompetencije, veštine

JEL Classification: M10 